\title{
Hepatitis B infection and liver transplantation
}

\author{
Eric M Yoshida MD FRCPC
}

\begin{abstract}
EM Yoshida. Hepatitis B infection and liver transplantation. Can J Gastroenterol 1997;11(5):462-468. Patients with chronic hepatitis B virus (HBV) infection have historically incurred high rates of allograft reinfection from extrahepatic reservoirs of $\mathrm{HBV}$, with worse long term outcome compared with that of transplant recipients without HBV infection. As a result, chronic HBV infection has been considered a contraindication for transplantation. Prophylaxis against HBV recurrence, in the form of passive immunization with high dose hepatitis B hyperimmunoglobulin and the antiviral agent lamivudine, has recently been demonstrated to decrease the risk of reinfection. With appropriate prophylaxis, liver transplantation can be a viable proposition for patients with HBV infection. Past experience and current status of HBV infection and transplantation are reviewed, with emphasis on the issues surrounding prophylaxis.
\end{abstract}

Key Words: Hepatitis B, Immunoglobulin, Lamivudine, Liver transplantation, Prophylaxis

\section{Hépatite $B$ et transplantation hépatique}

RÉSUMÉ : Les patients souffrant d'hépatite B chronique ont souvent présenté un taux élevé de réinfection de l'allogreffe provenant des importants réservoirs d'HBV, leur évolution à long terme étant moins favorable que celle des receveurs de transplantation indemnes d'infection à HBV. L'infection chronique au HBV a donc été considérée comme une contre-indication à la transplantation. La prophylaxie contre les récurrences de l'HBV sous forme d'immunisation passive au moyen de fortes doses d'hyperimmunoglobulines antihépatite $B$ et de l'antiviral lamivudine a récemment été associée à une réduction du risque de réinfection. Grâce à une prophylaxie appropriée, la transplantation hépatique peut donc être une solution envisageable chez les patients infectés au HBV. On passe ici en revue l'expérience acquise à ce jour et l'état actuel des connaissances sur l'HBV et la transplantation en mettant l'accent sur les questions entourant la prophylaxie.
$\mathrm{O}$ a global scale, chronic infection with the hepatitis $B$ virus (HBV) is a significant problem, affecting an estimated 300 to 400 million people worldwide. HBV prevalence in Canada is low but increasing. In areas with large numbers of immigrants from endemic areas, HBV may be a significant cause of end-stage liver disease. Cirrhosis and hepatocellular cancer (HCC) are the end results of chronic HBV infection. While therapy with interferon (IFN) may be of benefit to some patients, those with marginal hepatic reserve may decompensate with IFN therapy and are at risk of bacterial infections $(1,2)$. Although some decompensated patients may respond to IFN at substantially reduced doses, those with significant decompensation (ie, Child's class C) appear less likely to benefit (3). But it is precisely those with decompensated HBV infection who urgently require treatment. With most other liver diseases, patients in similar circumstances would routinely be offered liver transplantation. Until recently, however, HBV-related liver disease was considered a contraindication for transplantation in both Canada and the United States. HBV is no longer a contraindication at several American centres whereas chronic HBV infection remains a relative contraindication for transplantation in Canada. Outside of patients in investigational studies, few Canadians with HBV infection undergo transplantation.

British Columbia Transplant Society and the Department of Medicine, University of British Columbia, Vancouver, British Columbia

Correspondence: Dr EM Yoshida, British Columbia Transplant Society, East Tower, 4th Floor, 555 West 12th Avenue, Vancouver, British Columbia V5Z 3X7. Telephone 604-877-2100, fax 604-877-2111

Received for publication January 16, 1997. Accepted April 7, 1997 


\section{HISTORICAL CLINICAL OUTCOME AFTER TRANSPLANTATION}

Even with removal of the native liver, there are numerous extrahepatic reservoirs (4) in which HBV can be found (lymphoid tissue, bone marrow, kidney, pancreas, etc). Moreover, HBV DNA can be found in circulating mononuclear leukocytes post-transplant, even in the absence of HBV DNA in the allograft (5). The persistence of HBV in combination with post-transplant immunosuppression therefore creates an environment in which the transplanted liver is at high risk of reinfection.

Until recently, significant allograft reinfection, with poor allograft and patient long term survival, has been documented. American data from the United Network for Organ Sharing liver transplant registry (6) reveal that from 1987 to 1992, the 60-month survival for adults who received transplants for HBV was only $48 \%$, compared with $77 \%$ for both primary biliary cirrhosis and autoimmune hepatitis adult patients. In perhaps the largest study to date, Samuel and colleagues (7) reviewed the European experience, which included 334 patients (summarized in Table 1). They reported that patients with cirrhosis with active replication pretransplantation, as indicated by positivity for serum HBV DNA, had a three-year actuarial risk of allograft reinfection of $83 \%$. Those with cirrhosis who were HBV DNA hepatitis B early antigen $(\mathrm{HBe} \mathrm{Ag})$ seronegative had a three-year actuarial risk of $58 \%$. Certain subgroups - those who received transplants for acute fulminant HBV and delta agent coinfection - experienced markedly lower risks of reinfection: $17 \%$ and $32 \%$, respectively. Importantly, the European study determined that the overall three-year actuarial survival of those who developed allograft reinfection was only 54\%, versus $83 \%$ in those without allograft reinfection. Patients with allograft reinfection who received transplants for cirrhosis had an actuarial survival rate of only $44 \%$. Interestingly, approximately $80 \%$ of the patients in the study received some form of immunoprophylaxis.

From these data it is clear that patients who received transplants for hepatitis B have a significant risk of allograft reinfection and decreased survival compared with similar patients who are HBV-free. Patient outcome is related to viral load because those who are actively viremic (serum HBV DNA positive) are more likely to be reinfected than those not actively replicating (serum HBV DNA negative). Subgroups with delta agent coinfection and those who received transplants for acute fulminant hepatitis B are less likely to suffer allograft reinfection. In the latter case, it is likely that the immunological defences that resulted in fulminant hepatitis, combined with the short period of viral infection, result in a decreased viral burden, especially in extrahepatic tissues. In the former case, it is well accepted that the delta virus modulates $\mathrm{HBV}$ activity (8). Patients who received transplants for HBV-related HCC have even worse outcomes for survival, even when compared with patients who received transplants for non-HBV associated $\operatorname{HCC}(9,10)$. The very poor outcome in this group is only partly a direct result of malignancy. These patients have a greater risk of al-
TABLE 1

Summary of outcomes (three-year actuarial) after liver transplantation in patients with hepatitis B from the European Concerted Action on Viral Hepatitis Study $(n=334)$

\begin{tabular}{lcc}
\hline Subgroup & \% allograft reinfection & $\%$ survival \\
\hline Cirrhosis (HBV DNA+) & $83 \pm 6$ & NA \\
Cirrhosis (HBV DNA-) & $58 \pm 7$ & NA \\
All HBV cirrhosis & $67 \pm 4$ & 44 \\
Delta coinfection & $32 \pm 5$ (cirrhosis) & NA \\
Fulminant HBV & $40 \pm 16$ (fulminant) & \\
Allograft reinfection & $17 \pm 7$ & NA \\
No allograft reinfection & - & 54 \\
Overall & - & 83 \\
\hline
\end{tabular}

Data from reference 7. HBV Hepatitis B virus; NA Not available

lograft reinfection compared with those who received transplants for HBV-related cirrhosis, a one-year actuarial recurrence rate of $85.4 \%$ versus $65 \%$ (10). This increased risk of allograft recurrence in patients with HCC appears to include those whose HBV DNA was not actively replicating pretransplantation. The increased risk of reinfection associated with HCC may be a sequelae of peritransplant chemotherapy, but the possibility of micrometastases with increased extrahepatic viral burden is plausible (10).

\section{CLINICAL-PATHOLOGICAL ASPECTS OF ALLOGRAFT REINFECTION}

Allograft reinfection with HBV tends to be an aggressive disease, and the natural history follows that of chronic HBV infection in the nontransplant setting, but over a contracted time period (11). Acute hepatitis with a serum transaminase flare heralds allograft reinfection, and is followed by chronic hepatitis. End-stage cirrhosis can occur early, even a few years after transplantation, and there have been published reports of cirrhosis developing less than a year after transplantation $(11,12)$. A particularly dreaded form of allograft reinfection known as fibrosing cholestatic hepatitis $(\mathrm{FCH})$ is characterized clinically by progressive jaundice and liver failure. The histologic evolution of $\mathrm{FCH}$ is that of aggressively progressing fibrosis with scant inflammation, diffuse hepatocyte ballooning and numerous ground glass cells $(13,14)$. Aside from sporadic case reports of remission with nucleoside therapy $(15,16), \mathrm{FCH}$ is generally regarded as a fatal condition, with death typically occurring a few months after the initial diagnosis. FCH is generally accepted to result from direct cytopathogenicity of the virus due to enhanced viral transcription in the setting of immunosuppression $(17,18)$. FCH is not unique to liver transplantation. It has been reported to result from severe reactivation of latent HBV infection in renal (19) and bone marrow (20) transplant recipients and as a consequence of AIDS (21). There is no widely accepted efficacious medical treatment for $\mathrm{FCH}$ although the author's centre has experienced success with lamivudine (unpublished observation). In general, without 
TABLE 2

Summary of published results with the use of hepatitis B hyperimmunoglobulin

\begin{tabular}{|c|c|c|c|c|c|}
\hline $\begin{array}{l}\text { Centre } \\
\text { location }\end{array}$ & $\mathbf{n}$ & $\begin{array}{l}\text { Serum target } \\
\text { titre (IU/L) }\end{array}$ & $\begin{array}{l}\text { Overall \% } \\
\text { reinfection }\end{array}$ & Dose & Comment ${ }^{*}$ \\
\hline Paris (25) & 110 & 100 & $\begin{array}{l}29 \text { (two-year } \\
\text { actuarial) }\end{array}$ & $\begin{array}{l}\text { Typical dose: } 10,000 \mathrm{U} \text { IV anhepatic phase, } \\
10,000 \mathrm{U} \text { daily next } 6 \text { postoperative days } \\
\text { followed by } 10,000 \mathrm{U} \text { whenever serum titre } \\
>100 \mathrm{IU} / \mathrm{L}\end{array}$ & $\begin{array}{l}\text { HBV DNA+: } 29 \% \text { reinfection } \\
\text { HBV DNA-: } 96 \% \text { reinfection }\end{array}$ \\
\hline Berlin (26) & 45 & 100 & 42 (two-year) & $\begin{array}{l}10,000 \mathrm{U} \text { anhepatic phase, } 1000-2000 \mathrm{U} \text { first } \\
\text { postoperative week then doses as needed to } \\
\text { maintain serum titre }>100 \mathrm{IU} / \mathrm{L}\end{array}$ & $\begin{array}{l}\text { HBV DNA+: } 69 \% \text { reinfection; } \\
\text { HBV DNA-: } 28 \%\end{array}$ \\
\hline $\begin{array}{l}\text { San Francisco } \\
\text { (27) }\end{array}$ & 24 & $>500$ & 19 (two-year) & $\begin{array}{c}10,000 \cup \text { anhepatic phase, } 10,000 \cup \text { daily next } \\
6 \text { postoperative days then } 10,000 \cup \text { monthly }\end{array}$ & \\
\hline Virginia (28) & 27 & $\begin{array}{l}\text { >500: day 0-7; } \\
\text { >250: day 8-90; } \\
\text { > 100: after day } 90\end{array}$ & $\begin{array}{l}7 \text { (mean follow-up } \\
20 \text { months, } \\
\text { range } 2-55 \text { ) }\end{array}$ & $\begin{array}{l}\text { Typical dose: } 10,000 \mathrm{U} \text { anhepatic phase, } \\
10,000 \mathrm{U} \text { daily next } 6 \text { postoperative days, } \\
10,000 \mathrm{U} \text { weekly for initial } 4 \text { weeks then } \\
10,000 \mathrm{U} \text { every } 2 \text { weeks subsequent } \\
8 \text { weeks followed by } 10,000 \mathrm{U} \text { monthly }\end{array}$ & $\begin{array}{c}63 \% \text { of patients } \mathrm{HBeAg} \\
\text { seropositive }\end{array}$ \\
\hline Stanford (30) & 17 & 100 & $\begin{array}{l}0 \text { (mean follow-up } \\
11 \text { months) }\end{array}$ & $\begin{array}{c}10,000 \cup \text { anhepatic phase, } 10,000 \cup \text { daily next } \\
6 \text { postoperative days then } 10,000 \cup \text { monthly }\end{array}$ & $\begin{array}{l}53 \% \text { of patients } \mathrm{HBeAg} \\
\text { seropositive }\end{array}$ \\
\hline $\begin{array}{l}\text { Jerusalem } \\
\quad(31)\end{array}$ & 11 & 400 & $\begin{array}{l}9 \text { ( } 1 / 11 \text { patients) } \\
\text { (mean follow-up } \\
21.5 \text { months, } \\
\text { range } 8-42)\end{array}$ & $\begin{array}{l}10,000 \cup \text { anhepatic phase, } 10,000 \cup \text { daily next } \\
6 \text { postoperative days then } 10,000 \cup \text { monthly }\end{array}$ & $\begin{array}{l}82 \% \text { of patients } \\
\text { HBV DNA negative }\end{array}$ \\
\hline Nice (32) & 112 & 500 & $\begin{array}{l}7.59 \text { (five-year } \\
\text { actuarial) }\end{array}$ & $\begin{array}{l}10,000 \mathrm{U} \text { anhepatic phase, } 10,000 \mathrm{U} \text { daily next } \\
6 \text { postoperative days, } 10,000 \mathrm{U} 14,21 \text { and } \\
30 \text { days post-transplant then monthly }\end{array}$ & $\begin{array}{c}\text { All patients } \mathrm{HBV} \text { DNA, } \mathrm{HBeAg} \\
\text { negative } \\
\text { Overall: } 69 \% \text { Delta+ }\end{array}$ \\
\hline Seoul (33) & 13 & 100 & $\begin{array}{l}8 \text { ( } 1 / 13 \text { patients }) \\
(5 \text { patients died }<60 \\
\text { days, } 8 \text { survivors } \\
104-1095 \text { days })\end{array}$ & $\begin{array}{l}40,000 \mathrm{U} \text { anhepatic phase, } 40,000 \mathrm{U} \text { daily next } \\
6 \text { postoperative days then } 40,000 \mathrm{U} \text { monthly } \\
\text { except for } \mathrm{HBeAg} \text {-negative patients who } \\
\text { received } 10,000 \mathrm{U}\end{array}$ & HBeAg-: $15 \%(2 / 13)$ \\
\hline
\end{tabular}

*Hepatitis $B$ virus (HBV) DNA/hepatitis B early antigen (HBeAg) status refers to pretransplantation status. IV Intravenous

aggressive viral prophylaxis, retransplantation for allograft reinfection is futile because long term survival is poor, with the second allograft inevitably developing reinfection (22).

\section{IMMUNOPROPHYLAXIS WITH HEPATITIS B HYPERIMMUNOGLOBULIN}

Clearly the poor outcome of patients who received transplants for HBV is secondary to allograft reinfection. The aim of passive immunization of allograft recipients with hyperimmunoglobulin against hepatitis $B$ surface antigen ( $\mathrm{HBsAg}$ ) is to protect the transplanted liver in a manner similar to that of immunity conferred by vaccination. Over the past decade immunoprophylaxis has been attempted in various dosing regimens and for varying durations (Table 2). In the late 1980s and early 1990s small series from centres in Hannover (23) and Berlin (24) appeared to demonstrate that the long term administration of hepatitis B immunoglobulin was efficacious in preventing allograft reinfection. In a large study from Paris with 110 patients, Samuel et al (25) demonstrated that cirrhotic patients whose HBV DNA was not actively replicating pretransplantation $(n=24)$ had a significantly lower two-year actuarial risk of recurrence of $29 \%$, versus $96 \%$ in those whose HBV DNA was actively replicating $(n=16)$. Overall, the hepatitis $B$ cirrhotic group, as a whole, had an actuarial two-year risk of $59 \%$ while those who received transplants with coinfecting delta agent (and cirrhosis) had a much lower risk: only $13 \%(n=49)$. Those who received transplants for fulminant hepatitis $B(n=17)$ had no apparent risk $(0 \%)$ of reinfection. The monthly target anti-HBsAg titre in this study was $100 \mathrm{IU} / \mathrm{L}$. A group from Berlin (26), also aiming for $100 \mathrm{IU} / \mathrm{L}$, subsequently reported similar findings: $69 \%$ two-year allograft recurrence in those with viremia pretransplantation $(n=16)$, compared with $28 \%$ in those without detectable serum HBV DNA pretransplantation $(n=29)$. From these studies it appears that when aiming for a target titre of $100 \mathrm{IU} / \mathrm{L}$, beneficial immunoprophylaxis is largely limited to those whose HBV DNA was not actively replicating at transplantation. The collective European experience has convincingly demonstrated that although short term prophylaxis (less than six months) is of little benefit (7), long term administration appears to reduce the risk of allograft recurrence.

In the past few years several American centres have reported their experience using much higher doses of intravenous hepatitis B hyperimmunoglobulin (HBIG) than the Europeans. Terrault et al (27) at the University of California, San Francisco (UCSF) administered 10,000 U (45 mL) intravenously during the anhepatic phase of surgery, followed by $10,000 \mathrm{U}$ intravenously for the next six days and then monthly. Their recently published report (27) indicates 
a two-year recurrence rate of $19 \%(n=24)$ in a predominantly nonreplicating or delta coinfected group, compared with $76 \%$ in a cohort not receiving HBIG $(n=28)$. Trough anti-HBs titres were not prospectively used to adjust HBIG dosing but when analyzed retrospectively from stored samples, averaged 1275 IU/L. Those who experienced reinfection had trough titres less than $490 \mathrm{IU} / \mathrm{L}$. Although allograft reinfection was defined as $\mathrm{HBs} A g$ seropositivity, $67 \%$ of patients followed for longer than one year were positive for serum HBV DNA by polymerase chain reaction (PCR) even though liver biopsy immunoperoxidase stains were negative for both HBV core and surface antigen. McGory et al (28) at the University of Virginia used a similar basic dosing schedule as investigators at UCSF but gave extra doses of HBIG to maintain anti-HBs trough levels within a target range: more than $500 \mathrm{IU} / \mathrm{L}$ days 0 to 7 ; more than $250 \mathrm{IU} / \mathrm{L}$ days 8 to 90; and more than $100 \mathrm{IU} / \mathrm{L}$ thereafter. The majority of patients received HBIG weekly for four weeks, followed by HBIG every other week for eight weeks, before continuing with a monthly regimen. Ninety-three per cent of these patients $(n=27)$ remained seronegative for HBsAg and HBV DNA (by hybridization assay) at follow-up ranging from two to 55 months. Seventy-six per cent of patients were free from allograft recurrence at 12 months or longer post-transplantation. It is noteworthy that $63 \%$ of the patients were HBeAg seropositive pretransplantation. Although the $\mathrm{HBeAg}$ group required more frequent doses of HBIG to maintain target levels, the vast majority were not reinfected. The same investigators also reported successful retransplantation for allograft reinfection with their protocol (29). So and colleagues (30) at Stanford University recently presented their experience employing the same HBIG protocol as that used by UCSF (27), with similarly excellent results.

Elsewhere around the world, results of high dose HBIG prophylaxis protocols have been similar to or better than the American experience. Ilan et al (31) from Israel, aiming for trough levels of $400 \mathrm{IU} / \mathrm{L}$, reported only one recurrence in 11 patients. Only two patients in this cohort were serum HBV DNA positive pretransplantation. At the recent XVI International Congress meeting held in Barcelona, a group from Nice reported an incredible five-year actuarial reinfection rate of only $7.59 \%$ in 112 patients, none of whom was replicating pretransplantation (32). A somewhat unusual characteristic of this patient cohort was that $72 \%$ (77 of 107) of the cirrhotic patients were delta agent seropositive. Lastly, looking at viremic patients, Lee and co-workers (33) from Seoul, Korea reported administering heroic doses of HBIG 40,000 IU intravenously - for the first seven days, followed by monthly dosing of 40,000 IU to cirrhotics whose HBV DNA was actively replicating pretransplantation (11 of 13 patients were serum HBV DNA positive). They report only one patient with allograft recurrence, and none of their eight patients surviving greater than 60 days has been reinfected. The target titre of $\mathrm{HBIG}$ with this aggressive regimen was only $100 \mathrm{IU} / \mathrm{L}$, which confirms that patients whose HBV DNA is replicating pretransplantation can be successfully prophylaxed but will require substantially more HBIG than patients whose HBV DNA is nonreplicating/replicating at low level.

There are a number of concerns regarding the use of high dose HBIG for immunoprophylaxis. Despite its intravenous administration, the HBIG preparation available in Canada and used at American centres is licensed only for intramuscular use. A group from McGill University (34) has reported adequate titres of HBIG intramuscularly; however, large volume intramuscular injections may be problematic in the immediate postoperative period when transient thrombocytopenia and residual coagulopathy increase the risk of intramuscular hemorrhage. Patients may later complain of pain associated with the monthly intramuscular injections.

HBIG also contains antibody products, and intravenous infusion could result in immune-complex mediated symptoms. Although anaphylaxis has not been reported, myalgia and back pain may occur, which necessitates a slow infusion, occasionally with a narcotic premedication.

Furthermore, there is potential mercury toxicity from large frequent doses of HBIG regardless of the route of administration because HBIG preparations contain thimerosal as a preservative. American researchers routinely monitor serum mercury levels, and although mercury toxicity does not appear to be a problem, there has been one report of suspected neurological mercury toxicity after transplantation (35). Fortunately, this case was reversible after chelation therapy.

Another potential problem with HBIG use is the continued effectiveness of the product - in the nontransplantation setting, infection with HBV envelope-escape mutants have been reported after vaccination with monoclonal vaccines (36-38). Although the development of mutant strains has not yet been considered to be a significant problem in transplantation, HBV surface antigen mutations have also been reported after $\mathrm{HBIG}$ administration with allograft reinfection $(37,39-41)$.

The major concern regarding high dose HBIG is cost and availability. Terrault et al (27) from UCSF published their cost per patient: US $\$ 53,000$ for the first year and US $\$ 35,000$ for each year thereafter. The cost of HBIG from American suppliers has since increased. The continual availability of $\mathrm{HBIG}$ is also a concern because shortages from manufacturers have occurred. That these patients have a residual low level viremia, detectable by PCR if not hybridization assays, without other evidence of allograft reinfection (27), suggests that HBIG, if used as a single agent, may have to be continued indefinitely. A lack of availability of HBIG in the quantities necessary for adequate long term immunoprophylaxis would therefore leave patients at risk of allograft reinfection.

\section{PRIMARY PROPHYLAXIS WITH ANTIVIRAL AGENTS}

During its replicative life cycle, HBV undergoes a stage of RNA-dependent transcription (reverse transcription) (42) similar to that of the retroviruses (eg, HIV). The antiretroviral agent lamivudine ( 2 '-deoxy-3'-thiacytadine) has recently been demonstrated to be both well tolerated and effective at 
suppressing HBV replication in patients with chronic hepatitis $(43,44)$. Given the effectiveness of lamivudine in suppressing HBV replication and its widespread availability in oral formulation, it is tempting to consider HBIG-free prophylaxis employing this agent. Results of a recently published study (45) reported only one case of allograft reinfection in 10 patients surviving the immediate posttransplant period. This suggests that lamivudine monotherapy is the ideal agent for post-transplant prophylaxis, in terms of both effectiveness and economy. This optimism, however, must be tempered by recent reports of the emergence of lamivudine-resistant strains of HBV both in the transplant setting (46-49) and in nontransplanted patients (50). Bain and collaborators (46) at the University of Alberta recently reported that $50 \%$ of their long term surviving patients $(n=4)$ developed allograft reinfection with escape mutants more than a year after transplantation (46). The selection of lamivudine-resistant strains with subsequent allograft reinfection appears to be a widespread phenomenon; it has also been independently reported at the University of Miami (47) and in the United Kingdom (48). Lamivudine resistance may develop after prophylactic therapy or during treatment of allograft reinfection. In a recent interim analysis, $20 \%$ of patients $(n=10)$ treated for either post-transplant allograft reinfection or de novo infection developed resistant strains (49). In each analyzed case, the site of the mutation was identical to that of lamivudine-resistant HIV strains (51). The mutation has been identified as a point mutation within the YMDD (amino acid sequence 'tyrosine-methionine-aspartate-aspartate') motif of the RNA-dependent viral replicase. In each reported instance, the mutation is a point mutation substituting methionine for valine or isoleucine (ie, YVDD, YIDD) $(47-50,52)$. The exact incidence and significance of these YMDD mutations have yet to be defined but should emerge soon. Although allograft loss and worsened patient survival as a result of reinfection with lamivudine-resistant strains have not been reported, it should be noted that the studies to date have involved small numbers of patients with relatively short follow-up.

\section{TREATMENT OF ESTABLISHED ALLOGRAFT REINFECTION}

As mentioned previously, allograft reinfection has historically been associated with poor long term patient survival. Before lamivudine was widely available, there was no accepted treatment for this condition, although success was reported with parenteral ganciclovir $(15,53)$, oral ganciclovir (16) and oral famciclovir $(54,55)$. Although encouraging, these reports either involved small numbers of patients or were isolated case reports. The success of these conventional antiviral agents in allograft reinfection is, by no means, unequivocal because countering case reports of treatment failures with ganciclovir $(12,56)$ have also been published, as well as only mixed success with famciclovir (55). Of interest, famciclovir has not been noted to be of any benefit in treating allograft reinfection with lamivudine-resistant strains $(46,48)$. Ganciclovir and famciclovir have not been reported in any prophylaxis transplant study. Lamivudine reportedly is of benefit in the treatment of established allograft reinfection $(49,57)$, although if this antiretroviral agent becomes widely adopted in prophylaxis protocols, the problem of treating allograft recurrence with lamivudine-resistant strains will have to be addressed.

\section{CONCLUSIONS AND FUTURE TRENDS}

Clearly transplant hepatology has evolved such that it is now possible for patients with HBV infection to receive transplants. Subgroups of infected patients, eg, those with acute fulminant infection and delta agent coinfection, have an inherently lower risk of allograft reinfection, which is minimized even further with prophylaxis. Immunoprophylaxis with high dose HBIG appears to decrease the risk of reinfection to acceptable levels in patients chronically infected but whose HBV DNA was not actively replicating. If enough HBIG is given, even those with chronic, replicating infection may have an acceptable risk of reinfection. The main obstacles to high dose HBIG prophylaxis are those of continued availability of the product, practicability of administration and health care economics given the cost and long term duration of treatment.

Monotherapy prophylaxis with lamivudine is promising, but the long term outcome has not been determined. The many recent reports of reinfection with lamivudine-resistant strains, however, is disconcerting. Future prophylactic strategies may mirror the treatment of HIV disease with the administration of multiple antiviral agents. A reasonable current approach is to combine lamivudine administration with HBIG. Such an approach, reported favourably by Markowitz et al (58) at the University of California, Los Angeles, would allow the HBV DNA of more patients to become nonreplicating before receiving a transplant and remain so afterwards. Another strategy is to attempt conversion to a nonreplicating state pretransplantation with low dose IFN, as has been attempted at McGill University (34) with HBIG alone or in combination with lamivudine after transplantation.

There is a tremendous pool of potential transplant candidates with HBV in Canada, and the health care costs of any hepatitis $B$ transplantation program will be high. Liver transplantation, however, greatly improves the functional quality of life of recipients (59), and the majority return to work $(59,60)$. Overall costs of giving these patients transplants may therefore be offset because previously debilitated patients are able to return to a level of health such that they can once again contribute to society.

\section{REFERENCES}

1. Nevens F, Goubau P, Van Eyken P, et al. Treatment of decompensated viral hepatitis B-induced cirrhosis with low doses of interferon alpha. Liver 1993;13:15-9.

2. Hoofnagle HH, Di Bisceglie AM, Waggoner JG, et al. Interferon alpha for patients with clinically apparent cirrhosis due to chronic hepatitis B. Gastroenterology 1993;104:1116-21.

3. Perillo R, Tamburro C, Regenstein F, et al. Low-dose, titratable interferon alpha in decompensated liver disease caused by chronic infection with hepatitis B virus. Gastroenterology 1995;109:908-16. 
4. Dejean A, Lugassy C, Zafrani S, et al. Detection of hepatitis B virus DNA in pancreas, kidney and skin of two human carriers of the virus. J Gen Virol 1984;65:551-5.

5. Feray C, Zignego AL, Samuel D, et al. Persistent hepatitis B virus infection of mononuclear blood cells without concomitant liver infection. Transplantation 1994;49:1155-8.

6. Belle SH, Beringer KC, Detre KM. Trends in liver transplantation in the United States. In: Terasaki PI, Cecka JM, eds. Clinical Transplants 1993. Los Angeles: UCLA Tissue Typing Laboratory, 1994:19-35.

7. Samuel D, Muller R, Alexander G, et al. Liver transplantation in European patients with the hepatitis B surface antigen. N Engl J Med 1993;329:1842-7.

8. Krogsgaard K, Kdyger P, Aldershuile J, et al. Delta infection and suppression of hepatitis B virus replication in chronic HBsAg carriers. Hepatology 1987;7:42-5.

9. Chung SE, Toth JL, Reziez M, et al. Liver transplantation for hepatocellular cancer. Am J Surg 1994;167:317-21.

10. Wong PYN, McPeake JR, Portmann B, et al. Clinical course and survival after liver transplantation for hepatitis $B$ virus infection complicated by hepatocellular carcinoma. Am J Gastroenterol 1995;90:29-33.

11. Demetris HA, Todo S, Van Thiel DH, et al. Evolution of hepatitis B virus liver disease after hepatic replacement. Am J Pathol 1990;137:667-76.

12. Yoshida EM, Wolber RA, Mahmood WA, et al. Attempted resolution of acute recurrent hepatitis B in a transplanted liver allograft by the administration of ganciclovir. Transplantation 1994;58:956-8.

13. Davies SE, Portmann BC, O'Grady JG, et al. Hepatic histologic findings after transplantation for chronic hepatitis B virus infection, including a unique pattern of fibrosing cholestatic hepatitis. Hepatology 1991;13:150-7.

14. Walker N, Apel R, Kerlin P, et al. Hepatitis B virus infection in liver allografts. Am J Surg Pathol 1993;17:666-77.

15. Angus $\mathrm{P}$, Richards $M$, Boweden $S$, et al. Combination antiviral therapy controls severe post-liver transplant recurrence of hepatitis B virus infection. J Gastroenterol Hepatol 1992;8:353-7.

16. Jamal H, Regenstein F, Farr G, Perillo RP. Prolonged survival in fibrosing cholestatic hepatitis with long-term ganciclovir therapy. Am J Gastroenterol 1996;91:1027-30.

17. Lau JYN, Bain VG, Davies SE, et al. High-level expression of hepatitis $B$ viral antigens in fibrosing cholestatic hepatitis. Evidence that HBV may be cytopathic in liver grafts. Gastroenterology 1992;102:956-62.

18. Mason AL, Wick M, White HM, et al. Increased hepatocyte expression of hepatitis B virus transcription in patients with features of fibrosing cholestatic hepatitis. Gastroenterology 1993;105:237-44.

19. Lam PWY, Wachs ME, Somberg KA, et al. Fibrosing cholestatic hepatitis in renal transplant recipients. Transplantation 1996;61:378-81.

20. McIvor C, Morton J, Bryant A, et al. Fatal reactivation of precore mutant hepatitis B virus associated with fibrosing cholestatic hepatitis after bone marrow transplantation. Ann Intern Med 1994;121:274-5.

21. Fang JWS, Wright TL, Law JYN. Fibrosing cholestatic hepatitis in a patient with HIV and hepatitis B. Lancet 1993;342:1175. (Lett)

22. Crippin J, Foster B, Carlen S, et al. Retransplantation in hepatitis B a multicenter experience. Transplantation 1994;57:823-6.

23. Lauchart W, Muller R, Pichlmayr R. Long-term immunoprophylaxis of hepatitis $B$ virus reinfection in recipients of human liver allografts. Transplant Proc 1987;19:4051-3.

24. Blumhardt G, Neuhaus $P$, Bechstein WO, et al. Liver transplantation in HBsAg positive patients. Transplant Proc 1990;22:1517-8.

25. Samuel D, Bismuth A, Mathieu D, et al. Passive immunoprophylaxis after liver transplantation in $\mathrm{HBs} A g$-positive patients. Lancet 1991;334:813-5.

26. Langrehr JM, Lemmens HP, Keck H, et al. Liver transplantation in hepatitis B surface antigen positive patients with postoperative long-term immunoprophylaxis. Transplant Proc 1995;27:1215-6.

27. Terrault N, Zhou S, Combs C, et al. Prophylaxis in liver transplant recipients using a fixed dosing schedule of hepatitis $B$ immunoglobulin. Hepatology 1996;24:1327-33.

28. McGory RW, Ishitani MB, Oliveira WM, et al. Improved outcome of orthotopic liver transplantation for chronic hepatitis B cirrhosis with aggressive passive immunization. Transplantation 1996;61:1358-64.

29. Kiyasu PK, Ishitani MB, McGory RW, et al. Prevention of hepatitis B "recurrence" after a second liver transplant - the role of maintenance polyclonal HBIG therapy. Transplantation 1994;58:954-6.
30. So SKS, Esquivel CO, Imperial J, et al. Liver transplantation for $\mathrm{HBeAg}$-positive chronic HBV cirrhosis. Hepatology 1996;24:581A.

31. Ilan Y, Eid A, Tur-Kaspa R. Long-term prevention of recurrent hepatitis B virus after liver transplantation. Isr J Med Sci 1995;31:469-73.

32. Gugenheim J, Baldini E, Ouzan D, Mouiel J. Absence of initial viral replication and long-term high dose immunoglobulin administration improve results of hepatitis B virus recurrence prophylaxis after liver transpantation. Transplant Proc 1997;29:517-8.

33. Lee SG, Lee YJ, Kwon TW, et al. Unlimited-term passive immunoprophylaxis after liver transplantation in HBsAg-positive patients. Transplant Proc 1996;28:1176-7.

34. Tchervenkov J, Tector J, Ellas N, et al. Recurrence-free long term survival following liver transplantation for hepatitis B using interferon-alpha pre transplant and hepatitis B immune globulin (HBlg) post transplant. American Society of Transplant Physicians Fifteenth Annual Meeting, 1996:99.

35. Lowell JA, Burgess S, Shenroy S, et al. Mercury poisoning associated with hepatitis-B immunoglobulin. Lancet 1996;347:480. (Lett)

36. Carmen WF, Zanetti AR, Karayiannis R, et al. Vaccine-induced escape mutant of hepatitis B virus. Lancet 1990;336:325-9.

37. Zuckerman A, Harrison TJ, Oon CJ. Mutation in S region of hepatitis $B$ virus. Lancet 1994;343:737. (Lett)

38. Carman WF, Korula J, Wallace L, et al. Fulminant reactivation of hepatitis B due to envelope protein mutant that escaped detection by monoclonal HBsAg ELISA. Lancet 1994;345:1406-7.

39. Hawkins AE, Gilson RJ, Gilbert N, et al. Hepatitis B virus surface mutations associated with liver transplantation. J Hepatol 1996;24:8-14.

40. Ghany MG, Ayola B, Villamil FG, et al. HBV reinfection in liver transplant (LT) patients (PTS) who remained HBsAg negative post-LT. Hepatology 1996;24:1165A.

41. Carmen WF, Trauwein C, van Deursen FJ, et al. Hepatitis B virus envelope variation after transplantation with and without hepatitis B immune globulin prophylaxis. Hepatology 1996;24:489-93.

42. Civitico G, Wang UU, Lucombe C, et al. Antiviral stategies in chronic hepatitis B virus infection II. Infection of duck hepatitis $B$ virus in vitro using conventional antiviral agents and supercoiled-DNA active compounds. J Med Virol 1990;31:90-7.

43. Dienstag JL, Perillo RP, Schiff ER, et al. A preliminary trial of lamivudine for chronic hepatitis B infection. N Engl J Med 1995;333:1657-61.

44. Benhamou Y, Katlama C, Lunel F, et al. Effects of lamivudine on replication of hepatitis B virus in HIV-infected men. Ann Intern Med 1996;125:705-12.

45. Grellier L, Mutimer D, Ahmed M, et al. Lamivudine prophylaxis against reinfection in liver transplantation for hepatitis B cirrhosis. Lancet 1996;348:1212-5.

46. Bain VG, Kneteman NM, Ma MM, et al. Hepatits B patients with active replication and decompensated cirrhosis undergoing liver transplantation. Transplantation 1996;62:1456-62.

47. Bartholomew MM, Jansen RW, Jeffers LJ, et al. Hepatitis-B-virus resistance to lamivudine given for recurrent infection after orthotopic liver transplantation. Lancet 1997;349:20-2.

48. Ling R, Mutimer D, Ahmed M, et al. Selection of mutations in hepatitis $\mathrm{B}$ virus polymerase during therapy of transplant recipients with lamivudine. Hepatology 1996;24:711-3.

49. Perillo R, Rakela J, Martin P, et al. Lamivudine for hepatitis B after liver transplantation (OLT). Hepatology 1996;24:223A.

50. Naoumov NV, Chokshi S, Smith HM, Williams R. Emergence and characterization of lamivudine-resistent hepatitis B virus variant. Hepatology 1996;24:621A.

51. Tisdale M, Kemp SD, Parry NR, Larder BA. Rapid in vitro selection of human immunodeficiency virus type 1 resistant to 3'thiacytidine inhibitors due to a mutation in the YMDD region of reverse transcriptase. Proc Natl Acad Sci USA 1993;90:5653-6.

52. Tipples GA, Ma MM, Fischer KP, et al. Mutation in HBV RNA-dependent DNA polymerase confers resistance to lamivudine in vivo. Hepatology 1996;24:714-7.

53. Gish RG, Lau JY, Brooks L, et al. Ganciclovir treatment of hepatitis $B$ virus infection in transplant reipients. Hepatology $1996 ; 23: 1-7$. 
54. Kruger M, Tillmann HL, Trautwein C, et al. Famiclovir treatment of hepatitis B virus recurrence after liver transplantation: a pilot study. Liver Transplant Surg 1996;2:253-62.

55. Rabinovitz M, Dodson F, Rakela J. Famciclovir for recurrent hepatitis B (HBV) infection after liver transplantation (OLTX). Hepatology 1996;24:624A.

56. Gayowski T, Singh N. Lack of sustained efficacy of combination ganciclovir and foscarnet for hepatitis B virus recurrence after liver transplantation. Transplantation 1995;59:1629-30.

57. Ben-Ari Z, Shmueli D, Mor E, Shapira Z. Beneficial effect of lamivudine in recurrent hepatitis B post-liver transplantation. Hepatology 1996;24:1424A.

58. Markowitz J, Pakrasi A, Hollis P, et al. Efficacy of lamivudine for prophylaxis and treatment of hepatitis B in liver transplant patients. Hepatology 1996;24:222A.

59. Hunt CM, Tart JS, Dowdy E, et al. Effect of orthotopic liver transplantation on employment and health status. Liver Transplant Surg 1996;2:148-53.

60. Adams PC, Grant DR, Wall WJ. Employment after liver transplantation. Hepatology 1995;21:140-4. 


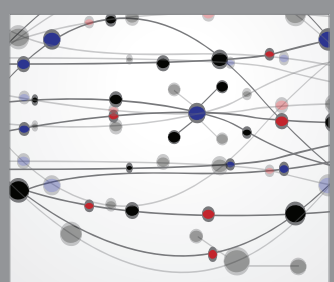

The Scientific World Journal
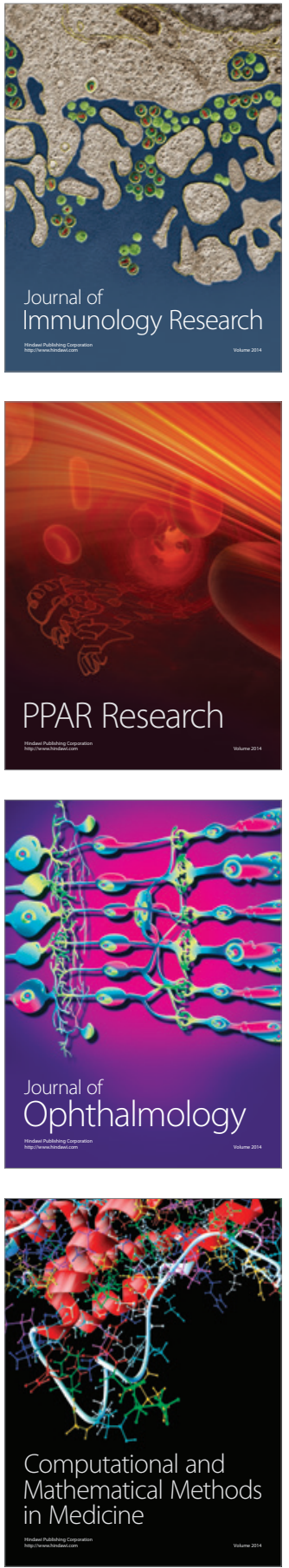

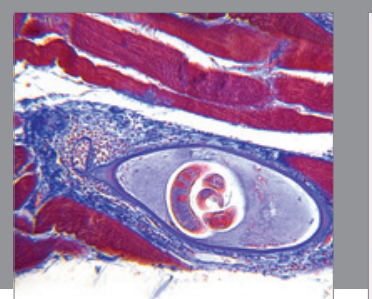

Gastroenterology Research and Practice

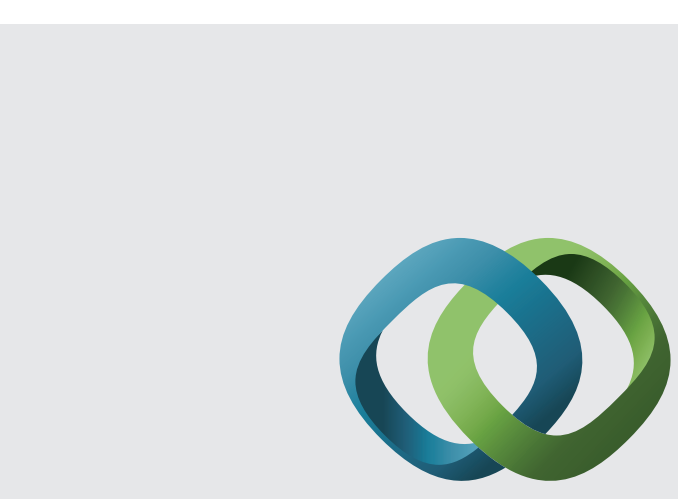

\section{Hindawi}

Submit your manuscripts at

http://www.hindawi.com
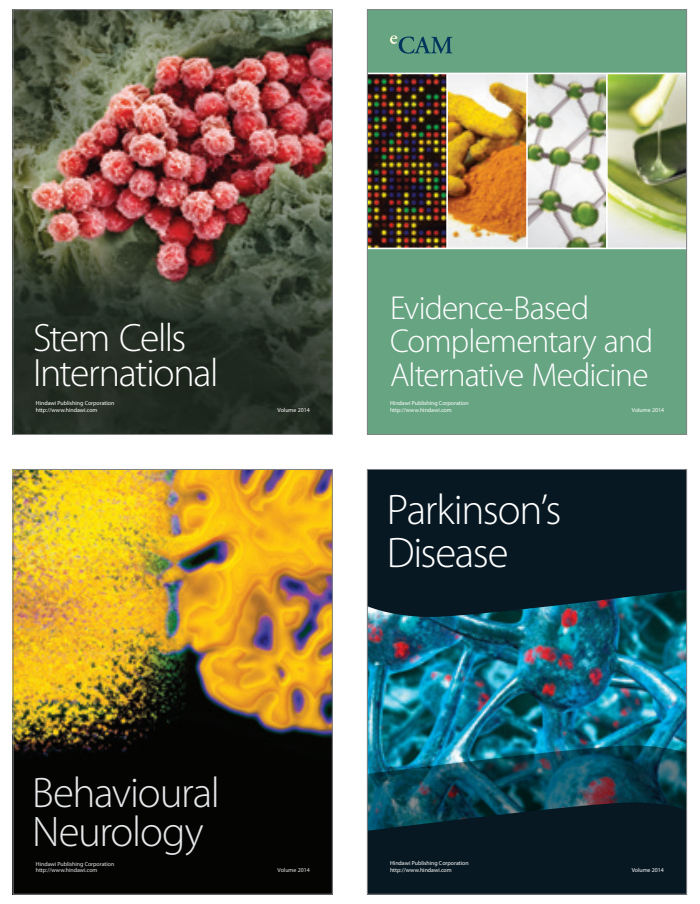
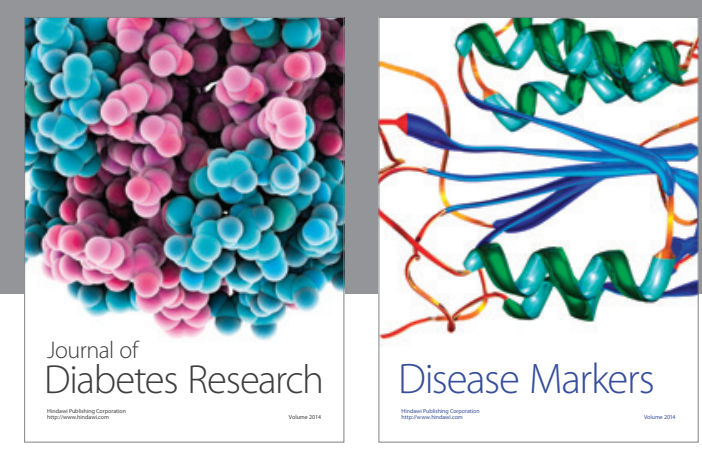

Disease Markers
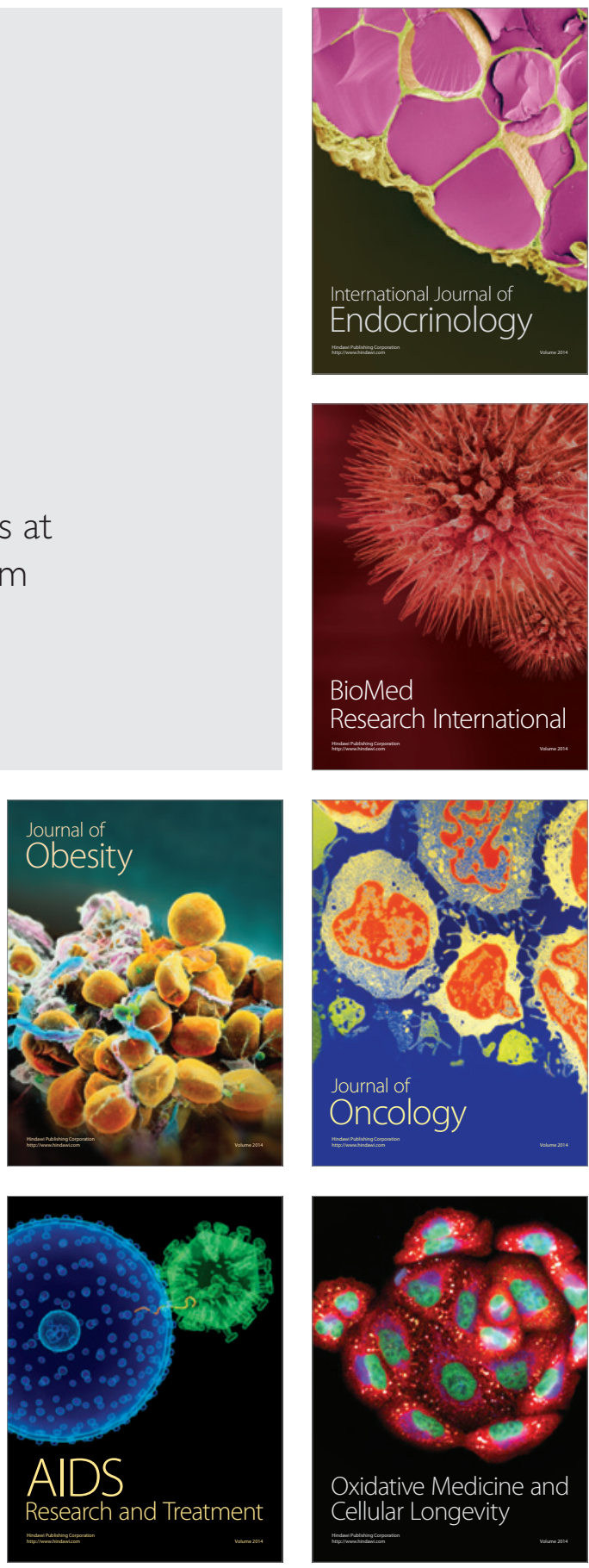